\title{
Climate Change: A Paradigm Shift for Investments?
}

\section{A Review of Evidence under Climate Science Research}

\author{
Sudeep Rathee \\ Indian Institute of Foreign Trade, \\ IIFT Bhawan, Qutub Institutional Area, New Delhi \\ Sheeba Kapil \\ Associate Professor, Finance \\ Indian Institute of Foreign Trade, New Delhi
}

\begin{abstract}
In light of the observed changes in climate patterns, this paper reviews the evidence forwarded under climate science research for analysing the climate related stresses on assets across different sectors. The review provides insights on the need for a shift in investment decisions and portfolio management activities. The paper follows an exploratory research method to focus on key climate science research themes. Thereby, the paper synthesizes the existing scientific information to identify those opportunities in climate change that require climate investments. Additionally, the research also discusses the points of uncertainty for climate investment that arise due the limitations of existing climate science related information and methods. The synthesis of climate science information in the paper will provide a foothold to the interdisciplinary research community in the area of sustainable investments for identification of investable climate assets and insights on the factors of climate science related uncertainty that need to be researched further for their impact on such climate investments.
\end{abstract}

Key words: Climate Investments, Climate Risks, Climate Science, Portfolio Choice, Investment Decision

\section{INTRODUCTION}

7 he all-encompassing characteristic of climate change inflicts its wider effect on the business and investment decisions. Over the past decade, the investors and business managers have realized that the influence of climate change has put the investment and business returns in a new costopportunity environment (Wellington and Sauer, 2005). Subsequently, it can be observed that a climate change related investment theme has evolved in due recognition of scientific, economic and policy driven awareness on human activity related Greenhouse Gas (GHG) emissions, primarily the Carbon Dioxide $\left(\mathrm{CO}_{2}\right)$ and resultant climate change. As a next step, the business and capital allocation decisions are expected to experience a long-term climate thematic shift from the current, carbon dioxide - intensive global economy towards a new trend of de-carbonised economic world order. The asset-

Journal of Technology

Management for Growing Economies

Vol. 4 No. 1 April 2013 pp. $49-68$

\section{CHITKARA 司 UNIVERSITY}

C)2013 by Chitkara University. All Rights Reserved. 
Rathee, S. Kapil, S. specific activities and sectors that are likely to be affected by this change are in the areas of - power production, buildings and other energy consumers, agricultural practices and land use change, air, surface and water transportation, industrial manufacturing, and municipal and industrial wastes (Stern, 2007). The prime reason for the affect is that assets falling in these sectors are the one which face highest amount of pressures from climate related natural occurrences and subsequent economic and policy actions as well. However, the scope of innovation and GHG emission reduction in these areas would also open new asset allocation opportunity-sets. Researches in finance have so far mostly focused on carbon trading, carbon finance and clean energy aspects of the climate change with some attention to climate related catastrophe risk modelling; (Alberola et. al, 2009; Borak et al., 2006; Chevallier 2011; Clean Edge, 2012; Fehr and Hinz, 2006; Garcia and Roberts, 2008). In recent years, an emerging broader approach, both in the academic and practitioner's researches, addresses a wider thematic change of investment strategy around climate change theme due to the rise in risks and opportunities of climate change in an adaptation and mitigation driven action plan (Ackerman and Stanton, 2012; Bugnion and Weiss, 2009; Mckinsey \& Company 2009). In such interdisciplinary background, two areas emerge as primary concerns of research for concluding a paradigm shift in portfolio investment decisions - (a) detailed analysis of the types and extent of physical impacts of climate change on assets, particularly from the viewpoint of incorporating uncertainties for probabilistic portfolio risk management models; (b) the identification of affected investable assets, specifically with the objective of listing the likely changes in investment opportunity-sets and consequent capital allocation decisions.

As first step in research on part (a) it can be observed that during last two decades, scientific groups across subject areas in physical sciences have analyzed and extrapolated the variables behind an unprecedented rise in global mean temperature and its effect on the climate cycle. The complexities of climate change have required research contribution along all the leading physical sciences to understand the extent and gravity of danger; however it would be difficult and out of scope of our present work to have an exhaustive survey of all the domains. In this paper, to answer the identified objectives, we will adopt a selective approach and provide a holistic view of researches under all the physical sciences together to understand the climate related risks and opportunities for investments. We will begin with reviewing the climate change concept in the first section. In second section, we will comprehend the human reasons and consequences of climate change. In third section, we identify a roadmap of adaptation and mitigation of climate change and

Journal of Technology Management for Growing Economies, Volume 4, Number 1, April 2013 
the expected costs of financing these efforts. There upon, in section four we would discuss the evolution of climate investment theme by reviewing the implications of climate change and the consequent risks and opportunities for the private investments. In the last section we will conclude the main findings of the paper and provide recommendation for research questions that can be explored by future researches.

\section{CLIMATE CHANGE: THE CONCEPT}

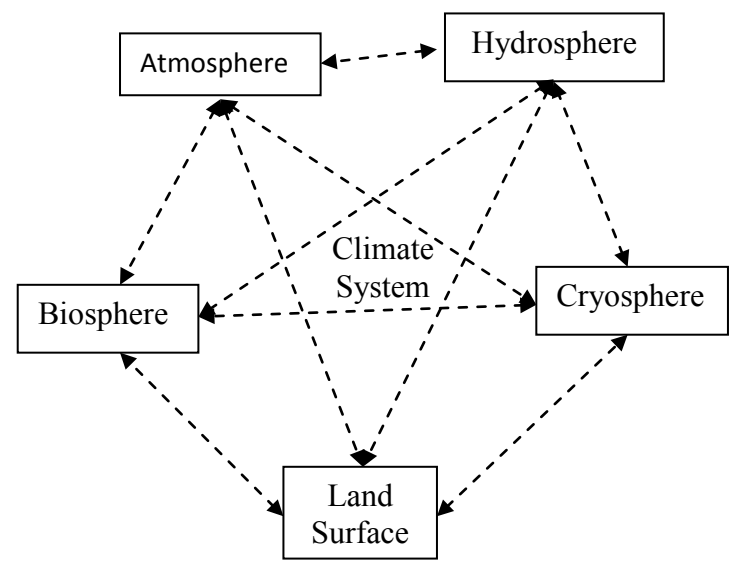

Figure 1: Climate Diamond

There are various definitions and classifications available on climate. Popularly, earth's climate is defined as average weather over long periods of time (Linacre and Geerts, 1997). Analytically, World Meteorological Organization (WMO, 2007) defines it as "the statistical description in terms of the mean and variability of relevant quantities over a period of time".

\section{Climate System}

Climate system can be termed as the overarching natural structure in which climate prevails. There are five natural forms that constitute this system atmosphere, hydrosphere, cryosphere, land surface, and Biosphere. Atmosphere is the blanket consisting of several layers of gases that exist above surface and is the first recipient of sun's radiations. Hydrosphere, as the name suggests are the water bodies like lakes, rivers and oceans that carry the liquid form of water. Cryosphere is that part of Earth where water exists in a frozen state like ice, snow, glaciers. Lithosphere or land surface is the land portion earth's surface. The fifth constituent, biosphere, comprises of terrestrial, marine, and freshwater beings including living organisms and their ecosystems. Climate 
Rathee, S.

Kapil, S.

system has taken its structural form due to the prevailing conditions of these five constituents. Furthermore, the variations and interactions among these constituents are factors of influence on climate system. Additionally, climate system is a function of some more natural and human-related forcings too such as volcanic eruptions, solar variations and human induced factors like land-use change, GHG emissions and the related changes in atmospheric greenhouse forcings.

\section{Climate Classification}

Over the period, the scientific research works have attempted to understand earth's climate through classifying it on various basis, such as, time, geography, vegetation types and climate variables like temperature, and precipitation. The classification based on 'time' has remained a subjective issue and often varies with the study objectives among the leading global climate research forums and climatologists. WMO's classical approach recommends averaging the climate related variables over a period of 30 years, whereas, studies reviewed in Intergovernmental Panel on Climate Change (IPCC) reports have used even lower averaging periods of 20 years. On the other hand, Palaeoclimatology studying climatologists have attempted to interpret climate for up to a million years (IPCC, 2007b; Mann et al., 1999; Mann et al., 2008). The choice of relevant variables for describing climate have also differed around combination of several variables such as temperature, precipitation, wind, atmospheric pressure, air particulates level, ocean currents, and humidity.

Another type of climate classification is based on vegetation types and their geographic zones. Köppen's climate classification and its further revisions are most popular reference on this typology (Institute for Veterinary Public Health, 2012; Köppen, 1918; Kottek et al., 2006; Peel, et al., 2007). The classification argues that native vegetation and plants are the best indictors for describing the location-specific climatic conditions. To develop these zones, it considers average annual and monthly temperatures, precipitation, and the seasonality of precipitation. Subsequently, five types of vegetations are described - tropical rain forest, temperate deciduous forests, boreal forests, hot desert flora and tundra. Some other referred classification systems for segregating geographies on basis of climate variables are - Holdridge life zones (Holdridge, 1967) which take precipitation, temperature, evapotranspiration and their relation with vegetation as key variables. Similarly, Thornthwaite (1948) classification is based on evapotranspiration and vegetation as climate variables. A detailed reference on current state of various climate variables and systems is presented in Blunden and Arndt (2012). 


\section{Greenhouse Gases (GHGs) and Radiative Forcing}

Research works have identified that in earth's atmospheric system natural feedback balance of vertical energy flow and climate balance is maintained among the intensity of incoming solar radiations, the thermal equilibrium provided by on-surface and oceanic conditions, and greenhouse effect produced by greenhouse gases (GHGs), aerosols, and water vapours (Carslaw et al., 2010; Held and Soden, 2000; Mitchell, 1989; Seinfeld and Pandis, 1998). The radiatively active GHGs absorb outgoing infrared and as a result earth's surface temperature remains higher than it would be otherwise. Kiehl and Trenberth, (1997) have calculated that an energy balanced earth system should release around $342 \mathrm{~W} / \mathrm{m}^{2}$. They further claim that in the absence of GHGs the mean temperature of earth would have been around $33{ }^{\circ} \mathrm{C}$ lower than what it is. The energy balance and the earth's warming are also cited as one of the key differences of life sustenance here on earth as compared to other planets in the solar system where there is no greenhouse visible. Hence, it can be concluded that GHGs and the corresponding greenhouse effect, in fact, have proved integral and essential for life's survival on earth.

Among GHGs, water vapour is the most effective GHG and its major supply source in the atmosphere has been cited as evapotranspiration from a warm hydrosphere (Thornthwaite, 1948) . Carbon dioxide $\left(\mathrm{CO}_{2}\right)$ is the next most abundant GHG that produces greenhouse effect. $\mathrm{CO}_{2}$ is the leading human activity related (hereon referred as, anthropogenic) GHG and has been mentioned in various researches as contributing the most to the increased levels of global warming that through its radiative forcing and greenhouse effect. Methane $\left(\mathrm{CH}_{4}\right)$, Nitrous Oxide $\left(\mathrm{N}_{2} \mathrm{O}\right)$, and Halocarbons are other constituent gases of GHGs. Naturally, GHGs have a life cycle that generally operates in an integrated movement among atmosphere, oceans, ice sheets and aboveunderground biosphere presence. However, the lifecycle of GHGs are of fairly long tenure, ranging from decades to a century (for $\mathrm{CO}_{2}$ ) Once released, they add up to the pre-existing levels in atmosphere and take several years before they are sequestered back into other mediums.

Amidst greenhouse effect of GHGs and the resulting warming of the planet, earth's climate interacts with GHGs through the infrared rays based thermal balance between the incoming solar radiations in the earth's atmosphere and the energy trapping of outgoing radiations by GHGs (Forster et al., 2007). The earth's climate variation in the energy flow as causal reaction to changes in the greenhouse constituents leads to modifications of energy trappings in atmosphere. The trapping capability called 'radiative forcing' is used as comparative measure for assessing the warming or cooling influences of
Climate Change:

A Paradigm Shift 
Rathee, S.

Kapil, S.

anthropogenic and natural factors on global climate. Radiative forcing of each of GHGs is mapped to the common denomination of $\mathrm{CO}_{2}$ through a quantitative scale called Global Warming Potential (GWP). GWP can be represented as:

$$
G W P_{1}=\frac{\int_{0}^{T} \alpha_{i}(\tau) d \tau}{\int_{0}^{T} \alpha_{1}(\tau) d \tau}, \quad i=1, \ldots, N
$$

Where ' $\alpha_{i}$ ' depends on the rate of change in instantaneous radiative forcing over a time period ' $\mathrm{T}$ ' due to the change in net accumulation of ' $\mathrm{i}$ ' 't $\mathrm{GHG}$ over this period. In simpler terms, GWP represents the marginal radiative forcing effect of instantaneous release of $1 \mathrm{~kg}$ of any radiative forcing agent with respect to the effect of increasing $1 \mathrm{~kg}$ of the reference gas (IPCC, 1990; Schmalensee, 1993). $\mathrm{CO}_{2}$ is considered as reference gas as its spectral absorption characteristics have been well studied and understood. As mentioned earlier, $\mathrm{CO}_{2}$ is the most abundant GHG after water vapour and is also most significant in terms of Radiative Forcing. All other GHGs are compared with $\mathrm{CO}_{2}$ on the basis of their GWP and hence weighed as Carbon dioxide equivalents $\left(\mathrm{CO}_{2} \mathrm{e}\right)$ for their warming potency. For example, Methane would be weighed as $12 \mathrm{CO}_{2}$ e. Leading GHGs and their characteristics are mentioned in table 1 below.

Table 1: Leading GHGs - Lifetime, Radiative Forcing, Global Warming Potential

\begin{tabular}{|c|c|c|c|c|c|c|}
\hline \multirow[b]{2}{*}{ Gas } & \multirow[b]{2}{*}{$\begin{array}{l}\text { For- } \\
\text { mula }\end{array}$} & \multirow[b]{2}{*}{$\begin{array}{c}\text { Lifetime } \\
\text { (years) }\end{array}$} & \multirow{2}{*}{$\begin{array}{l}\text { Radiative } \\
\text { Efficien- } \\
\text { cy } \quad(\mathrm{W} \\
\mathrm{m}^{-2} \mathrm{ppb}^{-1)}\end{array}$} & \multicolumn{3}{|c|}{ GWP Time Horizon } \\
\hline & & & & $20-y r$ & $100-y r$ & $500-\mathrm{yr}$ \\
\hline $\begin{array}{l}\text { Carbon diox- } \\
\text { ide }\end{array}$ & $\mathrm{CO}_{2}$ & Variable & $1.4 \times 10^{-5}$ & 1 & 1 & 1 \\
\hline Methane & $\mathrm{CH}_{4}$ & 12 & $3.7 \times 10^{-4}$ & 72 & 25 & 7.6 \\
\hline Nitrous oxide & $\mathrm{N}_{2} \mathrm{O}$ & 114 & $3.03 \times 10^{-3}$ & 289 & 298 & 153 \\
\hline HFC-23 & $\mathrm{CHF}_{3}$ & 270 & 0.19 & 12,000 & 14,800 & 12200 \\
\hline HFC-134a & & 14 & 0.16 & 3,830 & 1,430 & 435 \\
\hline $\begin{array}{l}\text { Sulphur hexa- } \\
\text { fluoride }\end{array}$ & $\mathrm{SF}_{6}$ & 3,200 & 0.52 & 16,300 & 22,800 & 32,600 \\
\hline
\end{tabular}

Source: (IPCC, 2007a)

Journal of Technology Management for Growing Economies, Volume 4, Number 1, April 2013 


\section{The Methodology of Climate Change Estimation}

The variation and complexity in the climate system require consistent information inputs of high quality, collected from climate sensitive locations across the globe. However, based on these raw inputs alone, detailed and incisive conclusion on climate variations cannot be arrived through general analytical techniques. Hence, scientists use innovative parameterizations and computational techniques under 'climate modelling' to derive inferences on those processes that cannot be described or calculated explicitly (Easterling et al., 2000). A 'climate model' is a mathematical description of the relationship between various climate related variables and generally draw its basic principles form physical, chemical, and biological processes and principles. Under climate modelling, the data collected over a timeline on climate sensitive variables such as - land and water temperature, precipitation and humidity levels, land and sea ice extent, cloud formation patterns and on wind speed and direction, from various geographic are modelled through complex statistical techniques. The models' outputs are thereupon studied for relevant inferences on climatic conditions. The technique of studying past climate change is referred to as 'Palaeoclimatology', whereby multiple climate sensitive indicators and related variations are modelled on timelines that may differ from decades to millenniums. Past data for such long durations is gathered from regions across the world through measures such as tree rings and ice cores.

Work on climate modelling techniques began in 1960s and subsequently, picked up in 1970s, as scientific community increasingly felt the inappropriateness of the prevalent physical science models for understanding the climate variability (Schneider and Dickinson, 1974; Smagorinsky et al., 1965). Afterwards, in the last six decades substantial progress has been achieved on developing the extrapolation and predictive power of quantitative mathematical models of climate (Mcguffie and Henderson-Sellers, 2001).

\section{REASONS AND CONSEQUENCES OF CLIMATE CHANGE}

\section{Anthropogenic Emissions and Climate Change: The Vicious Cycle}

The natural greenhouse effect adds $33{ }^{\circ} \mathrm{C}$ of warming to the climate systems. However, the anthropogenic emissions add up to the natural GHG emission levels and subsequently lead to an increase in the greenhouse effect and eventually the temperature levels. Naturally, due to a thermodynamic feedback flow among the diversely temperate but cyclically balanced natural elements, the heat generated by radiative forcing of atmospheric GHGs stays within a life sustaining range (Barnett et al., 1999). Some of these GHGs also have a residence time beyond centuries in the atmosphere (see Table 1) and

Journal of Technology Management for Growing Economies, Volume 4, Number 1, April 2013
Climate Change:

A Paradigm Shift 
Rathee, S.

Kapil, S. without much changes in the sink level, any rise in their emissions add up to the existing levels leading to a multiplier effect to the thermodynamic feedback. Various scientific research works have identified some primary indicators of the temperature rise that are visible across the climate diamond mentioned above. Since industrial revolution in mid 1800's, whereby the GHG emission - intensive activities increased globally, the climate indicators have seen a major upward shift (see Figure 2, 4 and 5) (Schneider, 1990; Crowley, 2000; IPCC, 2007a; Mann et al., 2008)

In atmosphere, rise in the above surface and above oceans air-temperature has been observed. Additionally, a global acceleration of the evapotranspiration process across the climate system and a consequent increase in the water vapour content in atmosphere has also been identified. This increase in the water vapour content further adds up to the GHG effect and radiative forcings. Increase in water vapour content over last few decades is now a confirmed fact in scientific findings and an indication of the existence of multiplier thermodynamic feedback process (IPCC, 2007a)

In the hydrosphere, rise in ocean heat content, increase in temperature over sea surface and the continuous increase in growth rate of sea level rising is also noted (Levitus et al., 2001). For Cryosphere, various researches report a rapid recession in sea-ice cover and snow covers in northern hemisphere along with the increased melting of glaciers (Mann et al., 1999). Whereas, in lithosphere, continuous spike in the global mean surface temperature over land has confirmed the fact of rising temperature (Mann, et al., 2008). In terms of the fifth, climatediamond constituent - biosphere, recent updates on widely accepted Köppen's climate classification maps of vegetation cover across the globe also confirm to the fact that climatic conditions have changed during the last century (Rubel and Kottek, 2010).

As depicted in Figure 2. and Figure 3. below, over this period, $\mathrm{CO}_{2}$ has seen a major spike in its atmospheric levels too. The most potent Carbon dioxide $\left(\mathrm{CO}_{2}\right)$ has risen up more than 30 percent during this period. Its current atmospheric levels are around 394 ppm from the pre 1750s levels of 280 ppm (IPCC, 2001; NASA, 2013; Siegenthaler and Oeschger, 1987). The changing $\mathrm{CO}_{2}$ levels, and the corresponding variations in the above-mentioned climate indicators are all pointing towards a strong causal relationship between rise in $\mathrm{CO}_{2}$ levels and climate change. Interestingly, over the same period of changes in atmospheric $\mathrm{CO}_{2}$ concentrations, the high $\mathrm{CO}_{2}$ emission driven human economic activities have also grown up rapidly. Picking from these two facts, over last five decades, scientific research works have consistently attempted to establish the exact nature of relationship between $\mathrm{CO}_{2}$ driven human economic activities, rise in atmospheric $\mathrm{CO}_{2}$ concentrations, and the changes in global climate systems.

Journal of Technology Management for Growing Economies, Volume 4, Number 1, April 2013 


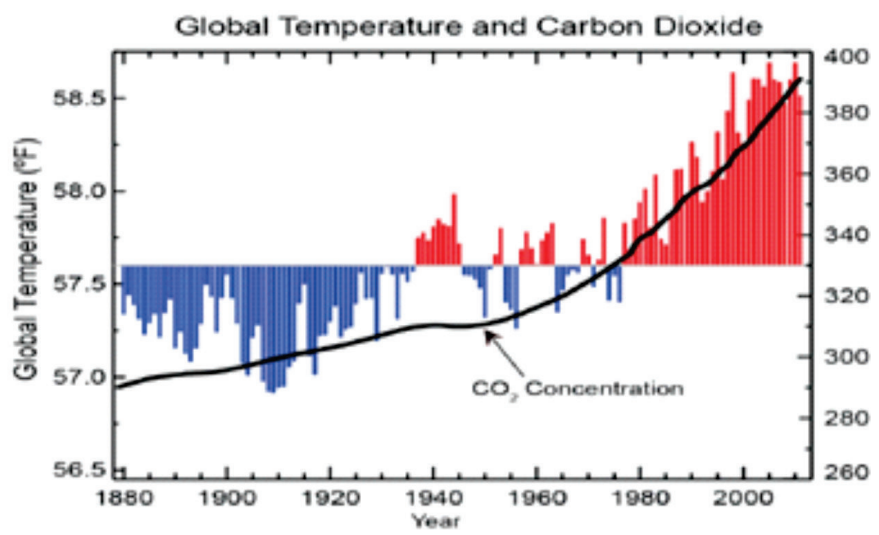

Climate Change:

A Paradigm Shift

Figure 2: Global Temperature and CO2 levels, since 1880

(Source: NASA, 2013)
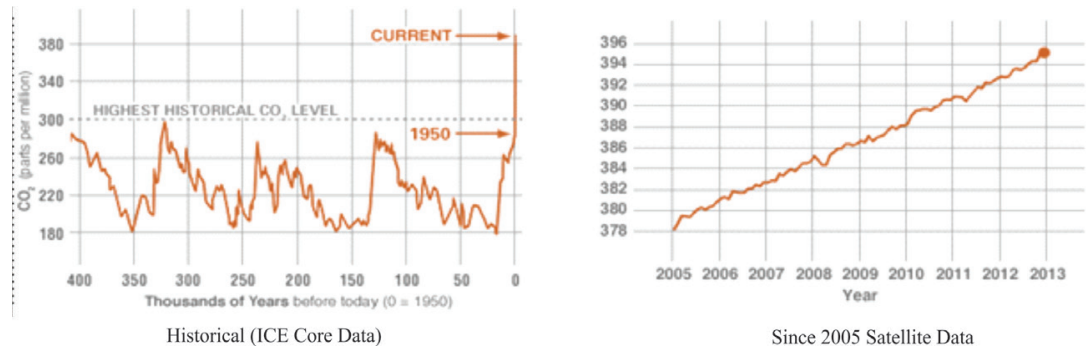

Figure 3: Atmospheric (CO2) levels (ppm) (Source: NASA, 2013)
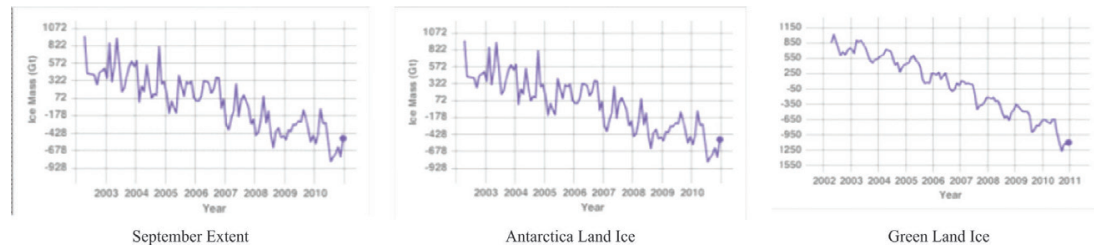

Figure 4: Ice Level Variations 2002 (Source: NASA, 2013)

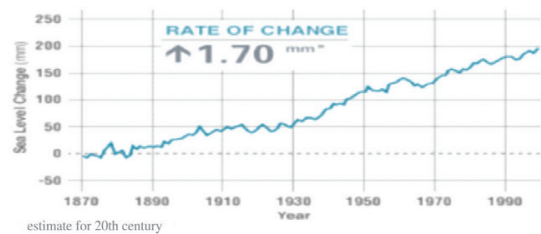

a) 1870 - 1990 (ground level data from tidal waves)

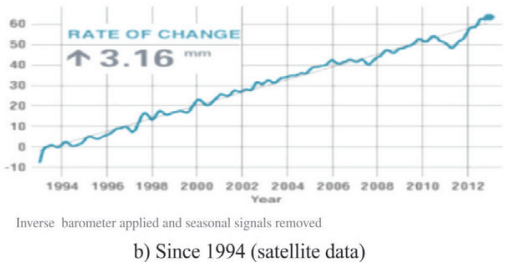

Figure 5: Sea Level Changes (Source: NASA, 2013) 
Rathee, S. Kapil, S.

Anthropogenic Emission SourcesScientific Studies on finding the GHG emitting culprit activities, suggest that the current high level of GHGs in atmosphere are a direct fallout of emissions in activities of assets in certain sectors, such as, - (a) burning of fossil fuels for meeting the increasing production, distribution and consumption of energy and transportation demands; (b) industrial manufacturing (c) real estate (d) by the ongoing alteration in Land Use and Land Use Change In Forestry (LUCLUCF) particularly the rapid deforestation in major carbon sinks - the tropical forests and (e) in agriculture (Bonan, 2008; Cline, 2007; IPCC, 2007a; Eliasch, 2008; Shukla et al., 1990). A thorough analysis of the individuals assets in these sectors provides a detailed list of emitting sectors and the underlying industries as listed in table 2 .

Table 2: Emission Sources

\begin{tabular}{|l|l|}
\hline \multicolumn{1}{|c|}{ Sector } & \multicolumn{1}{c|}{ Underlying primary Assets in Industries } \\
\hline Transportation & Aviation; Road \& Railways ; Shipping \& Waterways \\
\hline $\begin{array}{l}\text { Energy, Man- } \\
\text { ufacturing \& } \\
\text { Construction }\end{array}$ & $\begin{array}{l}\text { Alumnium and Ferrous; Cement ; Coal Mining ; Food, Bever- } \\
\text { ages and Tobacco }\end{array}$ \\
$\begin{array}{l}\text { Iron and Steel ; Machinery ; Non-Ferrous Metals; Oil and } \\
\text { Gas exploration, refining and processing; Petrochemicals; } \\
\text { Pulp,Paper \& Printing; Electricity and Heat Production; }\end{array}$ \\
\hline Real Estate & Residential \& Commercial Buildings \\
\hline $\begin{array}{l}\text { Land Use } \\
\text { Change }\end{array}$ & $\begin{array}{l}\text { Deforestation; Afforestation; Reforestation; Harvest / Manage- } \\
\text { ment }\end{array}$ \\
\hline Agriculture & $\begin{array}{l}\text { Agricultural Energy Use; Agricultural Soils; Fishery; Livestock } \\
\text { and Manure; Rice Cultivation }\end{array}$ \\
\hline Waste & Landfills; Waste water and other waste \\
\hline
\end{tabular}

Sources: Baumert et al., 2005; European Union, 2009; IPCC, 2007a; Mckinsey \& Company, 2009

\section{Climate Change Impacts}

The excess level of GHGs and the related increase heat trappings primarily affect in the form of rise in average global temperature and goes on to disturb the entire natural climate system. Increasing evidence from climate studies on various constituents of climate system is signalling that climate change is happening due to rise in net radiative forcing due to increaseing GHGs (IPCC, 1990; IPCC, 1996; IPCC, 2001; IPCC, 2007a; Levitus et al., 2001; Stern, 2007, Smith et al., 2009). The change in hyrdosphere including melting of glaciers, alterations in thermohaline circulation that carries warm water from equatorial regions to

Journal of Technology Management for Growing Economies, Volume 4, Number 1, April 2013 
the northern and southern latitudes alongwith the thermal expansion of oceans, threaten inundation of habitations along the coastal and other low-lying regions. The empirical data over warming of oceans during the last fifty years is repeatedly indicating that the estimates of the net radiative forcing of Earth's system have been possibly underestimated and dangers of rapid sea-level rise and more intense extreme weather conditions in coastal areas are even higher (Hansen et al., 1997; Levitus et al., 2005; Sydney et al., 2000). Such impacts of changes in global mean temperature and other climate variables are also expected to vary from having gradual and long-term impacts to singularities or tipping point natural shocks. The occurrence of the tipping point shocks would lead to massive and irreversible impacts. An anticipated event is expected to come from the collapse of Antarctic glaciers or Greenland ice sheets. This melting of large scale ice may lead to further climatic challenges through its interconnectedness with North Atlantic Meridional Overturning Circulation (Lenton et al., 2008). That would put severe stress on water systems, communities and ecosystems in higher altitude zones. Increasing vulnerability of Arctic indigenous communities and small island communities to warming has already been observed and is projected to accelerate (IPCC, 2007a). A typical self-accelerating effect of climate change is a feedback process, wherein warming event causes a change which leads to further warming. A positive feedback accelerates the occurrence of those events whereby either further GHGs are emitted or radiative forcing is increased due to reflection and absorption of additive infrared radiations. Climate change would have health implications in the form of acceleration of infectious and respiratory diseases, weakened immunities and new epidemic breakouts for humans and other living species too. The life sustaining ecosystems as whole are likely to suffer alternations and climate sensitive species will be forced towards extinction (Epstein et al., 2005).The plant and animal species and key life enabling biodiversity hotspots e.g., like coral reefs which are likely to be at an increased risk of extinction with rise in Global Mean Temperature (GMT) (IPCC, 2007a; Thomas et al., 2004; Lesser, 2007) has projected fears of widespread damage to ocean life, specifically corals, under ocean acidification and increases in ocean surface temperature in the range of $1^{\circ} \mathrm{C}$ to 3 ${ }^{\circ} \mathrm{C}$ (Knowlton and Jackson, 2008). Kurz et al (2008) have provided evidence of climate change instigated disease outbreaks in British Columbia forests that have resulted in net loss of biomass. In its four assessment reports, IPCC has forecasted increases in occurrences of severe weather conditions like drought, heat waves, tropical cyclones and intense precipitation events resulting in floods in several regions. Increase of GMT in the range of $1{ }^{\circ} \mathrm{C}$ is expected to raise vulnerability of various life forms against diseases. These shifts in climate patterns have already begun showing signs through increased frequency of occurrence of floods and droughts in certain climate-prone regions. Food security and biodiversity losses are looming large over these regions. The vulnerability of developing and poor
Climate Change:

A Paradigm Shift 
Rathee, S. Kapil, S. countries is even higher as financial capabilities and resources are limited due to poverty and low level of development.

\section{ROADMAP TO RECOVERY: ADAPTATION AND MITIGATION}

Some of the uncertainties in these above mentioned predictions are being discussed in the next section. Even in the presence of uncertainties about the precise impacts of changing climate, the size of risk and likely shift in market patterns calls for adoption of a precautionary approach in preparing for an adverse likelihood of risk and favourable approach for emerging opportunities. The likely gradual and tipping point outcomes of climate change can be tackled with two strategies adaptation and mitigation (Stern, 2007). Adaptation is about adjustment of socioeconomic and technical systems to the anticipated changes in climate due to the pattern shifts already occurred or are likely to occur at a minimum. It requires investment in developing protection measures from tackling the tipping point outcomes or catastrophe risks and in creating socio-economic infrastructure for enabling the communities to adjust to gradual changes. The detailed adaptation measures are provided in table 3 below.

Table 3: Sector-Grid on Climate Impacts and Adaptation

\begin{tabular}{|c|c|c|c|c|}
\hline Sector & Overall & Impact & $\begin{array}{l}\text { Catastrophe } \\
\text { (prone areas) }\end{array}$ & Adaptation \\
\hline Water & $\begin{array}{l}\text { Increased } \\
\text { water stress }\end{array}$ & $\begin{array}{l}\text { Variable Impacts of water avail- } \\
\text { ability - availability increases } \\
\text { in tropics and high latitudes ; } \\
\text { Decreases in mid-latitudes and } \\
\text { semi-arid low latitudes }\end{array}$ & $\begin{array}{l}\text { Drought (in } \\
\text { mid-latitudes and } \\
\text { semi-arid low } \\
\text { latitudes ) }\end{array}$ & $\begin{array}{l}\text { Water distribution } \\
\& \text { management }\end{array}$ \\
\hline $\begin{array}{l}\text { Ecosys- } \\
\text { tems }\end{array}$ & $\begin{array}{l}\text { Increasing } \\
\text { risk of spe- } \\
\text { cies extinc- } \\
\text { tion }\end{array}$ & $\begin{array}{l}\text { coral areas under threat; wildfire } \\
\text { risk; meridional overturning cir- } \\
\text { culation led ecosystem changes }\end{array}$ & $\begin{array}{l}\text { Biosystem } \\
\text { breakdown, } \\
\text { keynote species } \\
\text { extinction }\end{array}$ & $\begin{array}{l}\text { Environmental } \\
\text { restoration }\end{array}$ \\
\hline $\begin{array}{l}\text { Food and } \\
\text { agricul- } \\
\text { ture }\end{array}$ & $\begin{array}{l}\text { Variable } \\
\text { degrees of } \\
\text { impact on } \\
\text { productivity }\end{array}$ & $\begin{array}{l}\text { productivity changes in cereals } \\
\text { with latitude; mid -to-high } \\
\text { latitude productivity increases; } \\
\text { developing countries likely to } \\
\text { suffer due to loss in productivity, } \\
\text { developed regions likely to gain; } \\
\text { localised negative impacts on } \\
\text { small holders, subsistence farm- } \\
\text { ers and fishers }\end{array}$ & $\begin{array}{l}\text { Famine and } \\
\text { malnutrition }\end{array}$ & $\begin{array}{l}\text { Land conservation } \\
\text { Fertilizer } \\
\text { Weather resistant } \\
\text { Seed Insecticide } \\
\text { Soil improve- } \\
\text { ment Irrigation } \\
\text { Technology }\end{array}$ \\
\hline Coasts & $\begin{array}{l}\text { Increase in } \\
\text { damage from } \\
\text { floods and } \\
\text { storms }\end{array}$ & $\begin{array}{l}\text { Continuous sea-level rise; Glob- } \\
\text { al coastal wetlands threatened } \\
\text { for extinction; frequent coastal } \\
\text { flooding; }\end{array}$ & $\begin{array}{l}\text { coastal area } \\
\text { inundation; } \\
\text { mass-migration }\end{array}$ & $\begin{array}{l}\text { Sea defenses } \\
\text { Disaster Control } \\
\text { Infrastructure }\end{array}$ \\
\hline
\end{tabular}

Journal of Technology Management for Growing Economies, Volume 4, Number 1, April 2013 


\begin{tabular}{|c|c|c|c|c|c|}
\hline Sector & Overall & Impact & $\begin{array}{l}\text { Catastrophe } \\
\text { (prone areas) }\end{array}$ & Adaptation & $\begin{array}{l}\text { Climate Change: } \\
\text { A Paradigm Shift }\end{array}$ \\
\hline Health & $\begin{array}{l}\text { Increase in } \\
\text { probability } \\
\text { and causes } \\
\text { of certain } \\
\text { disease types }\end{array}$ & $\begin{array}{l}\text { Malnutrition, diarrhoeal, cardio- } \\
\text { respiratory, and infectious } \\
\text { diseases }\end{array}$ & $\begin{array}{l}\text { Increased mor- } \\
\text { bidity and mor- } \\
\text { tality from heat } \\
\text { waves, floods, } \\
\text { and droughts } \\
\text { (developing and } \\
\text { poor countries } \\
\text { more prone) }\end{array}$ & $\begin{array}{l}\text { Health infrastruc- } \\
\text { ture, Emergency } \\
\text { Health facilities } \\
\text { scale-up, develop- } \\
\text { ment of low-cost } \\
\text { recurring diseases } \\
\text { cure medicines, } \\
\text { Biotechnology, }\end{array}$ & 61 \\
\hline
\end{tabular}

Mitigation measures comprise of those activities that reduce human impact on climate in future. These cover investment in the reduction of emission intensity of economic activities carried out in GHG-intensive sectors specifically the ones identified in Table 2.

\section{DISCUSSION: CLIMATE CHANGE - INVESTMENT LINKAGES}

As inference from the above analysis, it can be recognized that climate change has put the investment portfolio choices in a new kind of risk-opportunity set. The emission-intensive activities identified for assets mentioned in Table 2 are likely to face continuous public and policy pressure for taking continual measures to curb their emissions or for mitigating the carbon footprints of the portfolio asset. Among the various choices, the two main options would be (a) to cut down on the operations and size of the concerned emission-intensive asset related activity, or (b) to further invest in improving the emission profile of these assets (UNCTAD, 2010). The earlier choice will have direct impact on the revenue potential and profit margins of the underlying investments. In the later option, investment in new capital assets and processes would be required resulting in net cash outflow from the underlying portfolio asset. On the other hand, the resulting climate risks will raise new kinds of cost for meeting the operational risks and financing of adaptation related activities in sectors identified in Table 3. However, at the same time, the challenges of climate change will also open new investable opportunities across asset classes. New investable assets will emerge for meeting the demands of the emerging climate related adaptation and mitigation sectors, in areas mention above. Simultaneously, the attractive climate thematic assets in traditional markets are likely to emerge through cost leadership and consequent improved profitmargins. These assets will avoid emission-related regulatory costs through better emission profiles and are expected to have more technical and operation efficiency in comparison to their emission-intensive competitors.

Subsequently, one can estimate that climate change emerges as an 
Rathee, S.

Kapil, S.

embedded theme for driving investment decisions concerned with such targeted assets. Hence, a climate change investment theme can be defined as a gamechanger and paradigm shift identified as a new investment trend or strategy targeted towards risk management and valuation of those assets, which are specifically influenced by climate change, related events.

\section{Climate Thematic Investment Risks}

Risk is defined as the unexpected variability of asset prices and / or earnings of an investment. The risks are further categorised in two types - business and financial (Jorion, 2007). Whereby, business risks are those risks that arise from business decisions and business environment of the underlying investment activity. Business risks can be analysed through identification of any adverse impacts on operational functions and / or revenue and sales of the business. In that regard, event related climate risks arise from natural calamities or catastrophes. The long-term but gradual climate changes, on the other hand, affect the sales and revenue of business activity through negative impacts on the fundamental supply-demand market dynamics. Second type of risk, financial risk, is the result of financial market activities. Market risk, liquidity risk, credit risk and operational risk are four types of financial risk that emanate from the changes in asset value due to financial or economic variables. Climate related financial risks are present in any of these four types in the underlying climate focussed asset or investment vehicle related financial activity. The impacts of climate change on shareholder's wealth are likely to be felt through:

a) Event driven losses, as increase in frequency and intensity of extreme weather related outcomes will cause earnings fluctuation and material losses of capital; the contagion of market-wide impacts would be felt in the rise of interest costs as well.

b) At the firm level, the additional costs of climate related emissions' mitigation along with the new investments in infrastructure for preventive adaptation against likely changes in the climatic conditions, could put additional pressures on profit margins. The impact would be more severe for those assets, which lie in highly climate sensitive sectors. For equity investments in oligopolistic and monopolistic market companies, rise in costs could be transferred to end consumers. However, in overly pricesensitive and perfectly competitive product markets, it may prove difficult to transfer the additional costs to consumers without affecting the marketshare.

(c) In light of likely regulatory changes on consideration of climate related

Journal of Technology Management for Growing Economies, Volume 4, Number 1, April 2013 
liabilities as a fiduciary duty both for the investee and portfolio managers, the non-performing investee's and portfolio managers may also face new kind of litigation costs and reputational challenges.

\section{Climate Thematic Investment Opportunities}

Investment opportunity is any asset or investment vehicle whose risk-return characteristics can improve the portfolio performance. The assets drive their value through the underlying business activity or financial characteristics. In modern portfolio theory, the investment attractiveness of a particular asset is calculated in a covariance framework. The wealth allocation decisions in the asset depend on both its mean-variance statistical performance as well as its portfolio risk diversification ability, identified through its association with other portfolio assets. Climate related investment opportunities are the rise in prospects of either newer investable assets or the improvements in characteristics and scope of exiting assets due to climate thematic favourable outcomes. The private investment community along with the public funds can play a decisive role in tackling the climate change problem through providing the necessary investments for financing the activities in the areas of climate adaptation and mitigation. At the same time a long-term strategic shift of investments in the portfolio context can be focused towards those assets, which are either climate friendly in their overall operations or are involved in producing de-carbonised value-add products or services. The Investors' participation in such assets can be channelized through appropriate investment products and vehicles with macro features categorizing them in traditional asset classes such as fixed income assets, equities, alternative investments like private equity, venture capital and commodities.

\section{CONCLUSION}

Climatic conditions are understood by observing the changes in several climate variables. The climate variables are direct determinants of climate investment theme due to their causal association with the risks and opportunities for commercial activities. The indirect determinants create relationship with cost-opportunity set through the changes caused by them in climate variables. Primarily, climate variables change as a result form variation in the heat balance of atmosphere. Radiative Forcing is the metric of thermal activity produced by various components of atmosphere, including the Greenhouse gases (GHGs). The anthropogenic GHG emissions post industrialisation have a significant effect in the increased radiative forcing amount which in turn resulted in increase in heat trappings and overall earth's temperature. The rise in temperature has consequently disturbed the climate system and related

Journal of Technology Management for Growing Economies, Volume 4, Number 1, April 2013
Climate Change:

A Paradigm Shift 
Rathee, S. Kapil, S.

climate variables. Scientific studies have now established, with high probability that with business-as-usual approach the growth rate of anthropogenic GHG emissions are going to keep an upward trend and are not expected to peakout in near future. The findings of this paper suggest that climate change is expected to have adverse impact on all five parameters of climate system viz. land surface characteristics, atmospheric composition, biosphere life forms, water availability and circulation patterns in hydrosphere and stability of Cryosphere. The possible lines of solutions for meeting the challenge of changing climate are adaptation and mitigation measures.

This paper observes that due to changing climate system, corporate activities and investments associated with them are likely to face physical risks to assets and commercial activities. Invariably, the operational costs, and capital expenditure will increase on the income statements and weather related catastrophe costs will decrease the asset values on balance sheets. Such risks need to be incorporated in investment policy to understand the true value of asset in long term. Investments associated with industries in six sectors namely transportation, energy, manufacturing \& construction, real estate, land use change, agriculture and waste have been identified as facing exposed to emission abatement pressures under the mitigation action plans. The business risk exposure to climate change faced by the investment activity need to be effectively managed through strategic actions that consists resource allocation and capability improvements. Simultaneously, new opportunities also open up for commercial activities and the associated investable asset classes as the adaptation and mitigation responses require thematic shift to low emission technologies and products. The six major emitting sectors also provide new avenues to develop and innovate in alternative products, processes and practices that have low emission footprint and high commercial output. Clean technology, energy efficiency, agrichemicals and infrastructure, water management and improved transportation are some of the industries identified that expected to grow in investment opportunities. This paper has identified determinants and risk-opportunities in a conceptual framework, the empirical reliability of determinants as input variables needs to be verified in further researches. This paper has limitations in describing the scope of climate opportunities on a viability level, the size and geographical spread of these investment opportunities have been left for further researchers to follow.

\section{REFERENCES}

Ackerman, F. and Stanton, E.A. (2012) 'Climate Risks and Carbon Prices: Revising the Social Cost of Carbon', Economics: The Open-Access, Open-Assessment E-Journal 6:10. http:// dx.doi.org/ 10.1016/j.energy.2012.01.053.

Alberola, E., Chevallier, J. and Cheze, B.(2009) 'Emissions compliances and carbon prices un-

Journal of Technology Management for Growing Economies, Volume 4, Number 1, April 2013 
der the EU ETS: a country specific analysis of industrial sectors', Journal of Policy Model, 31:3, pp. 446-462. http://dx.doi.org/ 10.5018.

Barnett, T.P., Hasselmann, K. and Cheliah, M. (1999) 'Detection and Attribution of Recent Climate Change: A Status Report', Bulletin of the American Meteorological Society, 80:12, pp. 2631-2659. http://dx.doi.org/10.1175/1520-0477(1999)080<2631:DAAORC $>2.0 . C O ; 2$

Blunden, J. and Arndt, D.S. (2012) 'State of the Climate in 2011', Bulletin of the American Meteorological Society 93, pp S1-S264.

Bonan, G.B. (2008) 'Forests and climate change: forcings, feedbacks, and the climate benefits of forests', Science, 320:5882, pp. 1444-1449. http://dx.doi.org/10.1126/science.1155121.

Borak, S., Truc, S., Hardle, W. and Weron, R. (2006) 'Convenience Yields for CO2 Emission Allowance Futures Contracts', Economic Risk Berlin N, 6.

Baumert, K. A., Herzog, T., \& Pershing, J. (2005) Navigating the Numbers: Greenhouse Gas Data and International Climate Policy, Climate Analysis Indicator Tool (CAIT) World Resources Institute.

Bugnion, V. and Weiss, J. (2009) 'Carbon as an Investment Opportunity' in A. Calvello', ed. Environmental alpha : institutional investors and climate change. Hoboken, New Jersey: John Wiley and Sons, pp.195-211. http://dx.doi.org/10.1002/9781118266748.ch9.

Carslaw, K. S., O. Boucher, D. V. Spracklen, G. W. Mann, J. G. L. Rae, S. Woodward, and M. Kulmala. (2010) 'A review of natural aerosol interactions and feedbacks within the Earth system', Atmospheric. Chemistry \&. Physics 10:4, pp. 1701-1737.

Chevallier, J. (2011) 'Banking and borrowing in the EU ETS: a review of economic modelling current provisions and prospects for future design', Journal of Economic Survey, 26:1, pp. 157 - 176. http://dx.doi.org/10.1111/j.1467-6419.2010.00642.x.

Clean Edge (2012) 'Clean Energy Trends 2012', San Francisco: Clean Edge.

Cline, W.R. (2007) 'Global Warming and Agriculture: Impact Estimates by Country', Peterson Institute.

Crowley, T.J. (2000) 'Causes of Climate Change Over the Past 1000 Years', Science, 289:5477, pp. 270-77. http://dx.doi.org/10.1126/science.289.5477.270

Easterling, D. R., Meehl, G. A., Parmesan, C., Changnon, S. A., Karl, T. R., and Mearns, L. O. (2000) 'Climate Extremes: Observations, Modeling and Impacts', Science, 289:5477, pp. 2068-74. http://dx.doi.org/10.1126/science.289.5487.2068

Eliasch, J. (2008) ', Climate Change: Financing Global Forests: The Eliasch Review', Routledge.

Epstein, P. R., Mills, E., Frith, K., Linden, E., Thomas, B., and Weireter, R. (2005) Climate Change Futures: Health, Ecological and Economic Dimensions, Center for Health and the Global Environment, Harvard Medical School, Boston, MA.

European Union (2009) Directive 2009/29/Ec of the European Parliament and of the council of 23 April 2009. Available from: http://eur-lex.europa.eu/LexUriServ/LexUriServ.do?uri=OJ:L:2009:140:0063:0087:en:PDF [Accessed 18 June 2012].

Fehr, M. and Hinz, J. (2006) 'A Quantitative Approach to Carbon Price Risk Modeling', Institute of Operations Research, ETH, Zurich.

Forster, P., Ramaswamy, V., Artaxo, P., Berntsen, T., Betts, R., Fahey, D. W., and Van Dorland, R. (2007) 'Changes in Atmospheric Constituents and in Radiative Forcing' in Solomon, S.; Qin, D.; Manning, M.; Chen, Z.; Marquis, M.; Averyt, K.B.; M.Tignor; Miller, H.L., eds. Climate Change 2007:The Physical Science Basis. Contribution of Working Group I to the Fourth Assessment Report of the Intergovernmental Panel on Climate Change, Cambridge, United Kingdom and New York, NY, USA: Cambridge University Press.

Garcia, B. and Roberts, E. (2008) 'Carbon Finance : Environemental Market Solutions to Climate Change', Yale School of Forestry and Environemental Studies.

Hansen, J., Sato, M. , Ruedy, R.,AU - Lacis, A., Asamoah, K., Beckford, K., Borenstein, S., Brown, E., Cairns, B., Carlson, B., Curran, B., de Castro, S., Druyan, L., Etwarrow, P.,
Climate Change:

A Paradigm Shift 
Rathee, S. Kapil, S.

Ferede, T., Fox, M., Gaffen, D., Glascoe, J., Gordon, H., Hollandsworth, S., Jiang, X., Johnson, C., Lawrence, N., Lean, J., Lerner, J., Lo, K., Logan, J., Luckett, A., McCormick, M. P., McPeters, R., Miller, R., Minnis, P. ,Ramberran, I., Russell, G., Russell, P., ,Stone, P., Tegen, I., Thomas, S., Thomason, L., Thompson, A., Wilder, J., Willson, R., Zawodny, J. (1997) 'Forcings and chaos in interannual to decadal climate change', Journal of Geophysical Research, 102:D22, 25679-25.

Held, I.M. and Soden, B.J. (2000) 'Water vapor feedback and global warming', Annual review of energy and the environment, 25:1, pp. 441-475. http://dx.doi.org/10.1146/annurev.energy.25.1.441

Holdridge, L.R. (1967), Life zone ecology, Tropical Science Center.

Institute for Veterinary Public Health, (2012) World Maps of KÖPPEN-GEIGER Climate Classification. Available from: http://koeppen-geiger.vu-wien.ac.at [Accessed 18 June 2012].

IPCC, (1990) Climate Change 1990: The IPCC Scientific Assessment. Report Prepared for IPCC by Working Group 1, Cambridge: Cambridge University Press.

IPCC, (1996) Climate Change 1995: the Science of Climate Change, Working Group I contribution to the Second Assessment Report of the Intergovernmental Panel on Climate Change, Cambridge, UK: Cambridge University Press.

IPCC (2001) Climate Change 2001: The Scientific Basis. Contribution of Working Group I to the Third Assessment Report of the Intergovernmental Panel on Climate Change, Cambridge, UK: Cambridge University Press.

IPCC, (2007a) Climate Change 2007: Synthesis Report, Contribution of Working Groups I, II and III to the Fourth Assessment Report of the Intergovernmental Panel on Climate Change, Cambridge: Cambridge University Press.

IPCC, (2007b) Glossary, Annex II, Climate Change 2007: Synthesis Report, IPCC Fourth Assessment Report: Climate Change 2007, [Online] Available at: http://www.ipcc.ch/publications and data/ar4/syr/en/annexessglossary-a-d.html [Accessed 12 June 2012].

Jorion, P. (2007) Value-at-Risk: The New Benchmark for Managing Financial Risk (3rd ed), New York: McGraw-Hill.

Kiehl, J.T. and Trenberth, K.E. (1997) 'Earth's Annual Global Mean Energy Budget', Bulletin of the American Meteorological Society, 78:2, pp.197-208. http://dx.doi.org/10.1175/1520 $-0477(1997) 078<0197:$ EAGMEB $>2.0 . C O ; 2$

Knowlton, N. and Jackson, J.B.C. (2008) 'Shifting baselines, local impacts, and global change on coral reefs', PLoS biology, 6:2, pp. e54. http//dx.doi.org/10.1371/journal.pbio.006005.

Köppen, W. (1918) 'Klassifikation der Klimate nach Temperatur, Niederschlag und Jahresablauf (Classification of climates according to temperature', precipitation and seasonal cycle) Petermanns Geogr. Mitt, 64, pp.193-203, pp. 243-248.

Kottek, M., Grieser, J., Beck, C., Rudolf, B., and Rubel, F. (2006),'World Map of the KöppenGeiger climate classification updated', Meteorologische Zeitschrift, 15:3, pp. 259-263.

Kurz, W. A., Dymond, C. C., Stinson, G., Rampley, G. J., Neilson, E. T., Carroll, A. L., and Safranyik, L. (2008) 'Mountain pine beetle and forest carbon feedback to climate change', Nature, 452:7190, pp. 987-990. http://dx.doi.org/10.1038/nature06777.

Lenton, T. M., Held, H., Kriegler, E., Hall, J. W., Lucht, W., Rahmstorf, S., and Schellnhuber, H. J. (2008) 'Tipping elements in the Earth's climate system', Proceedings of the National Academy of Sciences, 105:6, pp.1786-1793. http://dx.doi.org/10.1073/pnas.0705414105

Lesser, M. (2007) 'Coral reef bleaching and global climate change: Can corals survive the next century?', Proceedings of the National Academy of Sciences, 104:13, pp. 5259-5260.

Levitus, S., Antonov, J. and Boyer, T. (2005) 'Warming of the world ocean, 1955-2003', Geophysical Research Letters, 32:2, pp.1-4. http://dx.doi.org/10.1029/2004GL021592

Levitus, S., Antonov, I.J., Wang,J., Delworth, T.L. and Dixon, K.W. (2001) 'Anthropogenic warming of Earth's climate system', Science, 292:5515, pp.267- 270. http://dx.doi. org/10.1126/science.1058154.

Journal of Technology Management for Growing Economies, Volume 4, Number 1, April 2013 
Linacre, E. and Geerts, B., (1997) Climates and Weather Explained, London: Routledge.

Mann, M.E., Bradley, R.S. and Hughes, M.K., (1999) 'Northern hemisphere temperatures during the past millennium: Inferences, uncertainties, and limitations', Geophysical Research Letters, 26:6, pp. 759-762. http://dx.doi.org/10.1029/1999GL900070.

Mann, M. E., Zhang, Z., Hughes, M. K., Bradley, R. S., Miller, S. K., Rutherford, S., \& Ni, F., (2008) 'Proxy-based reconstructions of hemispheric and global surface temperature variations over the past two millennia', Proceedings of the National Academy of Sciences, 105:36, pp. 13252-13257. http://dx.doi.org/10.1073/pnas.0805721105

Mcguffie, K. and Henderson-Sellers, A., (2001) Forty Years of Numerical Climate Modelling. International Journal of Climatology, 21:9, pp. 1067-1109. http://dx.doi.org/10.1002/ joc.632.

Mckinsey \& Company, (2009) Pathways to a Low-Carbon Economy: Version 2 of The Global Greenhouse Gas Abatement Cost Curve.

Mitchell, J.F.B., (1989) 'The "greenhouse" effect and climate change' Reviews of Geophysics, 27:1, pp.115-139.

NASA, (2013) Global Climate Change: Key Indicators. Available from: http://climate.nasa. gov/key indicators [Accessed 8 Janauary 2013]

Nordhaus, W.D. (1990) 'Contribution of Different Greenhouse Gases to Global Warming: A New Technique for Measuring Impact', Yale University, Department of Economics, Mimeo, February.

Peel, M.C., Finlayson, B.L. and McMahon, T.A., (2007) 'Updated world map of the KöppenGeiger climate classification', Hydrology and Earth System Sciences Discussions Discussions, 11:2, pp.439-473.

Rubel, F. and Kottek, M. (2010) 'Observed and projected climate shifts 1901-2100 depicted by world maps of the Köppen-Geiger climate classification', Meteorologische Zeitschrift, 19:2, pp. 135-41. http://dx.doi.org/10.1127/0941-2948/2010/0430.

Schmalensee, R. (1993) ‘Comparing Greenhouse Gases for Policy Purposes', The Energy Journal, 14:1, pp.245-255

Schneider, S.H. (1990), Global Warming - Are We Entering the Greenhouse Century, 1st Vintage Books. http://dx.doi.org/10.2307/3673499.

Schneider, S.H. and Dickinson, R.E. (1974) 'Climate modelling', Reviews of Geophysics and Space Physics, 12:3, pp. 447-493. http://dx.doi.org/10.1029/RG012i003p00447.

Seinfeld, J.H. and Pandis, S.N. (2012) Atmospheric Chemistry and Physics: From Air Pollution to Climate Change, New York: Wiley-Interscience.

Shukla, J., Nobre, C. and Sellers, P. (1990) 'Amazon deforestation and climate change'. Science, 247:4948, pp. 1322-1325. http://dx.doi.org/10.1126/science.247.4948.1322.

Siegenthaler, U. and Oeschger, H. (1987) 'Biospheric CO2 emissions during the past 200 years reconstructed by deconvolution of ice core data', Tellus B, 39:1-2, pp.140-154. http://dx. doi.org/10.1111/j.1600-0889.1987.tb00278.x.

Smagorinsky, J., Manabe, S. and Holloway, J.L. (1965) 'Numerical Results from a nine-level general circulation model of the atmosphere', Monthly Weather Review, 93:12, pp. 727768.

Smith, J. B., Schneider, S. H., Oppenheimer, M., Yohe, G. W., Hare, W., Mastrandrea, M. D., and Van Ypersele, J. P., Patwardhan, A., Burton, I., Corfee-Morlot, J., Magadza, C.H.D., Füssel, H., Pittock, A.B., Rahman, A., Suarez, A. and Ypersele, J.V. (2009) 'Assessing dangerous climate change through an update of the Intergovernmental Panel on Climate Change (IPCC) "reasons for concern"" Proceedings of the National Academy of Sciences, 106:11, 4133-4137. http://dx.doi.org/10.1073/pnas.0812355106

Stern, N. (2007), The Economics of Climate Change: The Stern Review, Cambridge and New York: Cambridge University Press.

Sydney, L., Antonov, J.I., Boyer, T.P. and Stephens, C. (2000) 'Warming of the World Ocean'.
Climate Change: A Paradigm Shift 
Rathee, S. Kapil, S.
Science, 287:5461, 2225-2229. http://dx.doi.org/10.1126/science.287.5461.2225.

Thomas, C. D., Cameron, A., Green, R. E., Bakkenes, M., Beaumont, L. J., Collingham, Y. C., and Williams, S. E.,(2004), 'Extinction risk from climate change', Nature, 427:6970, 145148. http://dx.doi.org/10.1038/nature02121.

Thornthwaite, C.W. (1948) 'An Approach toward a Rational Classification of Climate', Geographical Review, 38:1, pp. 55-94.

UNCTAD (2010) World Investment Report 2010: Investing in a Low-Carbon Economy. New York and Geneva: United Nations Publications.

Wellington, F., and Sauer, A. (2005) 'Framing climate change risk in portfolio management'. World Resources Institute report, CERES Inc., Boston.

WMO, (2007) Understanding Climate. [Online] Available at: http://www.wmo.int/pages/ themes/climate/understanding_climate.php [Accessed 18 June 2012].

Sudeep Rathee, is Ph.D Research Scholar, Department of Finance, Indian Institute of Foreign Trade (IIFT), New Delhi, India. Email: sudeep@iift.ac.in.

Sheeba Kapil, is Associate Professor, Department of Finance, Indian Institute of Foreign Trade (IIFT), New Delhi, India. Email: sheebakapil@iift.ac.in. 